\title{
Mineral formation during bacterial sulfate reduction in the presence of different electron donors and carbon sources
}

\section{Xiqiu Han ${ }^{1}$, Logan Schultz ${ }^{2}$, Weiyan Zhang ${ }^{1}$, Jihao Zhu $^{1}$, Fanxu Meng ${ }^{3}$ and Gill G. Geesey $^{4 *}$}

${ }^{1}$ Key Laboratory of Submarine Geosciences \& The Second Institute of Oceanography, State Oceanic Administration, Hangzhou 310012, China

${ }^{2}$ Department of Chemical and Biological Engineering, Center for Biofilm Engineering, Montana State University, Bozeman, MT 59717-3980

${ }^{3}$ Key Laboratory of Marine Ecosystem and Biogeochemistry \& The Second Institute of Oceanography, State Oceanic Administration, Hangzhou 310012, China

${ }^{4}$ Thermal Biology Institute and Department of Microbiology, Montana State University, Bozeman, MT 59717-3520, email: gill_g@erc.montana.edu

\section{${ }^{*}$ Corresponding author}

Running title: Mineral formation during bacterial sulfate reduction

Key words: carbonate, monohydrocalcite, marine cold seeps, bacterial sulfate reduction, electron donor 
Sulfate-reducing bacteria have long been known to promote mineral precipitation. However,

50 the influence of electron donors (energy sources) and carbon sources on the minerals formed

51 during sulfate reduction is less well understood. An investigation was therefore undertaken to

52 determine how these nutrients affect sulfate reduction by the bacterium Desulfovibrio alaskensis

53 G20 in a marine sediment pore water medium. Monohydrocalcite and a small amount of calcite

54 formed during sulfate reduction with formate as the electron donor; Mg-phosphates and calcite

55 precipitated when hydrogen served as the electron donor and when acetate and dissolved

56 inorganic carbon served as carbon sources; and greigite and elemental sulfur were deposited

57 when lactate was used as the electron donor and carbon source. The experimental results were

58 generally consistent with geochemical modeling, suggesting that it may be possible to predict the

59 processes and conditions during formation of these minerals in natural environments. 


\section{INTRODUCTION}

Microorganisms are known to promote the precipitation of minerals (Bavendamm, 1932; Greenfield, 1963; Nadson, 1928). Sulfate-reducing bacteria (SRB) often contribute to the formation of carbonate minerals in marine and other sulfate containing saline environments (Breibart et al., 2009; Gunatilaka et al., 1984; Krause et al., 2012; Vasconcelos and McKenzie, 1997; Wright, 1997; Wright, 1999). For example, dolomite and Mg-calcite precipitate under hypersaline and moderately saline/brackish conditions, respectively, in the presence of SRB in highly reducing, organic C-rich coastal lagoons (Vasconcelos and McKenzie, 1997; Vasconcelos et al., 1995). Correspondingly, aragonite and Mg-calcite are common in marine cold seeps where the coupling of anaerobic oxidation of methane and sulfate reduction favors their formation (Suess, 2014). Other carbonate phases such as (proto)-dolomite, siderite and ikaite (calcium carbonate hexahydrate) also occur under specific conditions at cold seep sites (Greinert and Derkachev, 2004; Han et al., 2004; Wang et al., 2014). Sulfate-reducing bacteria also promote precipitation of phosphate-containing minerals (e.g. hydroxyapatite) under suboxic to anoxic conditions in ancient and modern upwelling systems (Alsenz et al., 2015; Arning et al., 2009; Schulz and Schulz, 2005).

Redox reactions associated with respiration and growth of SRB can lead to mineral formation. (Birnbaum and Wireman, 1984; Da Silva et al., 2000; Douglas, 2005; Ferrer et al., 1988; Rivadeneyra et al., 2006; Sanchez-Roman et al., 2007; Vasconcelos and McKenzie, 1997; Wright, 1999). While it is well established that SRB-mediated changes in aqueous phase chemistry promote mineral formation, less is known about how electron donors and carbon sources for bacterial respiration and growth influence the process. Nevertheless, these 
83 metabolites play an important role in mineral precipitation (Dupraz and Visscher, 2005; Visscher

84 et al., 1998; Warthmann et al., 2000).

85 Bacterial culture experiments, theoretical calculations and geochemical modeling have

86 shown that $\mathrm{pH}$, alkalinity and carbonate mineral saturation vary depending on the type of

87 electron donor used for sulfate reduction but have not related results to the formation of specific

88 minerals (Gallagher et al., 2012). Other studies have shown that the consumption of a mixture of

89 organic compounds and production of extracellular and cell wall material during sulfate

90 reduction by Desulfovibrio alaskensis G20 (formerly D. desulfuricans G20, hereafter referred to

91 as G20) promoted the formation of calcite that differed in morphology from that formed

92 abiotically, but did not determine how utilization of different carbon and energy sources

93 influenced mineralogy and morphology (Bosak and Newman, 2005). The minerals formed

94 during bacterial sulfate reduction may, however, offer insight to the electron donors used for the

95 reaction in environments such as marine cold seeps where their identity remains elusive

96 (McGlynn et al., 2015; Wegener et al., 2015).

97 Here we investigate the minerals formed when formate, hydrogen, or lactate serve as the

98 electron donor for sulfate reduction by G20 in a medium chemically similar to marine sediment

99 pore water from the sulfate-methane transition zone (SMTZ) of a marine cold seep system in the

100 South China Sea where there is evidence of bacterial sulfate reduction and carbonate mineral

101 formation (Suess, 2005). Since formate, hydrogen and lactate are found in cold seep sediments

102 (Heuer et al., 2009; Kendall et al., 2007; Larowe et al., 2008), they may serve as electron donors

103 for SRB in these systems.

104 G20 is a mutant strain of D. desulfuricans G100A that was isolated from an oil well (Wall et

105 al., 1993; Weimer et al., 1988). This SRB was selected for the study because it has previously 
served as a model organism to study sulfate reduction and carbonate mineral precipitation in

107 seawater (Bosak and Newman, 2003; Bosak and Newman, 2005). The metabolism of electron

108 donors and carbon sources during sulfate reduction is also better understood in G20 than in other

109 SRB known to be involved in the formation of natural mineral deposits (Hauser et al., 2011;

110 Labrenz et al., 2000; Li et al., 2009; Li et al., 2011; Postgate, 1984; Price et al., 2014; van Lith et

111 al., 2003; Weimer et al., 1988).

112 Lactate serves both as an electron donor for sulfate reduction and as a sole carbon source for

113 growth of G20 (Li et al., 2009; Li et al., 2011; Postgate, 1984; Weimer et al., 1988). When

114 formate serves as electron donor, both acetate and dissolved inorganic carbon (DIC) are required

115 as carbon sources for cell growth since formate carbon is not assimilated by G20 (Li et al., 2009;

116 Voordouw, 1995). Both acetate and dissolved inorganic carbon (DIC) are also required as carbon

117 sources for growth of G20 when hydrogen serves as electron donor for sulfate reduction (Li et

118 al., 2009; Voordouw, 1995). However, G20 does not use acetate as an electron donor for sulfate

119 reduction (Weimer et al., 1988). Hydrogen also serves as a supplementary electron donor for

120 G20 in formate and lactate medium, but only after the organic electron donor becomes limiting

121 (Khosrovi et al., 1971). The results reported here suggest that the types of minerals formed in a

122 marine sediment pore water medium offer insights into the reactions and conditions at the time

123 of their formation.

124 2. METHODS

$125 \quad$ 2.1 Medium preparation, inoculation and incubation.

126 The bacterial cultivation medium contained inorganic salts at concentrations found in

127 sediment pore water at the SMTZ of a marine cold seep system in the South China Sea (Table 1).

128 The exceptions were salts of ammonium (as $\mathrm{NH}_{4} \mathrm{Cl}$ ) and phosphate (as $\mathrm{Na}_{2} \mathrm{HPO}_{4}$ ) which were 
129 elevated to provide a sufficient amount of nitrogen and phosphorus for microbial growth. The

130 medium also contained lactate, formate or acetate at a concentration higher than that reported in

131 SMTZ pore water (Kendall et al., 2007) to allow sufficient sulfate reduction and cell growth for

132 detectable mineral formation. The initial concentration of electron donor relative to electron

133 acceptor (sulfate) favored electron acceptor (sulfate) limitation of sulfate reduction (i.e.,

134 exhaustion of electron acceptor before electron donor), while the initial concentration of the

135 organic carbon source, nitrogen source and phosphorus source favored nitrogen-limited growth

136 (i.e., exhaustion of $\mathrm{NH}_{4} \mathrm{Cl}$ before $\mathrm{Na}_{2} \mathrm{HPO}_{4}$ and lactate or acetate), conditions known to exist in

137 some carbonate mineral-forming environments (Joye et al., 2004). Wolf's vitamins were also

138 added to the medium to support growth of G20 (Table 1).

139 All medium components except vitamins were prepared as a single solution. Hydrochloric

140 acid was added to achieve a pH of 7.5 after autoclave sterilization. Wolf's vitamins were

141 prepared as a concentrated solution as previously described (Atlas, 2004), filter-sterilized and

142 aseptically added to the cooled sterile medium components.

143 The sterile acetate, formate or lactate medium (100 ml) was aseptically introduced to

144 autoclave-sterilized butyl rubber-stoppered serum bottles (120-ml vol), each containing an iron

145 finishing nail (five bottles of each medium). The iron nail served as a substitute for the unknown

146 form of naturally-occurring iron that reacts with soluble sulfide to form insoluble iron sulfides in

147 cold seep sediments. The contents of the serum bottles were purged with a sterile stream of

148 hydrogen for 1 hour through the butyl rubber stopper to establish a reduction potential favoring

149 sulfate reduction and to provide hydrogen as sole electron donor for sulfate reduction in acetate

150 medium. Like formate and lactate, the amount of hydrogen relative to sulfate in acetate medium

151 favored depletion of electron acceptor before electron donor. 
One bottle of each medium was used to assess the effects of medium preparation on $\mathrm{pH}$

153 and $\mathrm{Ca}$ and $\mathrm{Mg}$ concentration ( $\mathrm{t}=0$ ). Two bottles of each medium were inoculated through the

154 septum with two drops of a fresh culture of G20 using a hydrogen-purged syringe and needle

155 and incubated at $25{ }^{\circ} \mathrm{C}$ for 10 months ( $\mathrm{t}=10 \mathrm{mo}$ ) to promote bacterial sulfate reduction. The

156 two remaining bottles of each medium were incubated at the same temperature and period of

157 time under sterile anaerobic conditions to serve as abiotic controls.

\section{$158 \quad 2.3$ Analysis of aqueous phase.}

159 A 0.2-ml sample was collected from each bottle and centrifuged at 7,300 x g for $10 \mathrm{~min}$ at 25

$160{ }^{\circ} \mathrm{C}$ to pellet any suspended solids. A $0.1-\mathrm{ml}$ subsample of the supernatant fraction was then

161 diluted 1:100 with a solution consisting of $1 \% \mathrm{HNO}_{3}$ and $0.5 \% \mathrm{HCl}$ using trace metal grade

162 acids and the concentration of Ca and Mg measured by ICP-MS using an Agilent 7500c series

163 instrument equipped with a Babington type nebulizer. A standard solution (Agilent, 5183-4688)

164 containing a mixture of 25 elements was used in combination with internal standards (Li, Sc, Ge,

$165 \mathrm{Y}, \mathrm{In}, \mathrm{Bi})$ to calibrate the instrument to obtain the concentration of elements in the samples. The

166 standard deviation among replicates of the standards was 4-8\%. The pH and total alkalinity (TA)

167 of the medium was measured using a Fisher Accument Model 825MP pH meter and a Mettler

168 Toledo T50 alkalinity analyzer, respectively.

\section{$169 \quad 2.4$ Analysis of solids.}

170 The medium in the bottles was filtered to collect solids which had formed during incubation.

171 The solids retained on the filter were dried overnight at $30{ }^{\circ} \mathrm{C}$ in a nitrogen atmosphere and

172 analyzed within a week of collection. The mineral phases were determined by X-ray diffraction

173 (XRD) using a Panalytical X'Pert Pro MRD with Cu K-alpha radiation generated at $45 \mathrm{kV}$ and 
$17440 \mathrm{~mA}$ in $0.0167^{\circ}$ per step in a $2 \theta$ angle interval between $5^{\circ}$ and $70^{\circ}$. The Rietveld full-pattern

175 fitting method was applied for quantitative mineralogical phase analysis.

176 The morphology and elemental composition of the solids were determined by scanning

177 electron microscopy (SEM), energy-dispersive X-ray spectroscopic analysis (EDS) and electron

178 microprobe analysis (EMPA). A subsample of the solid phase was transferred to a specimen

179 holder, sputter-coated with platinum for 30 seconds at 20 mA using a JEOL JFC 1600 Auto Fine

180 coater and examined using a Hitachi S-4800 scanning electron microscope with an Oxford X-

181 MAX-20 energy-dispersive X-ray spectroscopic analysis system at an accelerating voltage of 15

$182 \mathrm{kV}$. To assess the effect of coating, separate subsamples were deposited directly on silver foil

183 and subjected to single particle elemental analysis without sputter-coating. Carbon sputter-coated

184 samples were also analyzed using a JXA-8100 electron microprobe analyzer operated at an

185 accelerating voltage of $15 \mathrm{kV}$, a beam current of $20 \mathrm{nA}$ and a spot size less than $20 \mu \mathrm{m}$. The

186 elemental composition of sample constituents obtained by EDS and EMPA was compared with

187 that of known stoichiometric minerals available at http://webmineral.com to determine the

188 possible mineral composition of the sample.

\section{$189 \quad 2.5$ Chemical modeling.}

190 The program SpecE8 within the Geochemist's Workbench program version 10.0.4

191 (Rockware, Golden, Colorado, U.S.A.) employed the MINTEQ database (thermo_minteq.dat) to

192 describe the SMTZ sediment pore water and the nutrient-enriched culture media, including the

193 extent of complex formation involving the cations $\mathrm{Ca}^{2+}$ and $\mathrm{Mg}^{2+}$ and anions $\mathrm{PO}_{4}{ }^{2-}$, formate

$194\left(\mathrm{CHO}_{2}{ }^{-}\right)$, acetate $\left(\mathrm{CH}_{3} \mathrm{CO}_{2}{ }^{-}\right)$and lactate $\left(\mathrm{C}_{3} \mathrm{H}_{5} \mathrm{O}_{3}{ }^{-}\right)$. Since the $\mathrm{pH}$ and organic acid concentrations

195 were not measured in the SMTZ pore water of the South China Sea sediments, the program 
assumed a $\mathrm{pH}$ of 7.9 and that acetate, formate and lactate concentrations were the same as those

197 measured in SMTZ pore water in cold seep sediments of Akan Bay, AK (Kendall et al., 2007).

198 The program React within the Geochemist's Workbench was used to simulate sulfate

199 reduction and determine whether the observed mineral phases that formed during experiments

200 are predicted on the basis of the measured changes in aqueous phase chemistry. The following

201 reactions were used to describe sulfate reduction with each electron donor:

202 Hydrogen as electron donor in acetate medium:

$$
4 \mathrm{H}_{2}+\mathrm{SO}_{4}{ }^{2-}+\mathrm{H}^{+} \rightarrow \mathrm{HS}^{-}+4 \mathrm{H}_{2} \mathrm{O}
$$

(Eq. 1) (Meulepas et al., 2010)

204 Formate as electron donor in formate medium:

$$
4 \mathrm{CHO}_{2}^{-}+\mathrm{SO}_{4}{ }^{2-}+\mathrm{H}_{2} \mathrm{O} \rightarrow \mathrm{HS}^{-}+4 \mathrm{HCO}_{3}{ }^{-}+\mathrm{OH}^{-}
$$

Lactate as electron donor in lactate medium:

$$
2 \mathrm{C}_{3} \mathrm{H}_{5} \mathrm{O}_{3}{ }^{-}+\mathrm{SO}_{4}{ }^{2-} \rightarrow 2 \mathrm{C}_{2} \mathrm{H}_{3} \mathrm{O}_{2}^{-}+\mathrm{HS}^{-}+2 \mathrm{HCO}_{3}^{-}+\mathrm{H}^{+}
$$

The input values were based on the initial concentration of medium components provided in

Table 1 after adjustments based on initial $(\mathrm{t}=0)$ and final $(\mathrm{t}=10 \mathrm{mo})$ measured elemental

211 concentrations were not measured in experiments, the model predicts changes in aqueous

212 chemistry and mineral saturation for sulfate reduction from 0 to $100 \%$. The model assumes a

213 source of solid iron, which removes all soluble sulfide (as iron sulfide) during sulfate reduction

214 (Bosak and Newman, 2003). Because minerals form during progressive sulfate reduction (and

215 not only at the end), the model incorporates the precipitation of the primary minerals formed

216 during sulfate reduction over a series of 10 steps: monohydrocalcite (MHC) in formate medium,

217 hydroxyapatite in acetate medium, and greigite in lactate medium.

\section{3. RESULTS}




\subsection{Chemistry of aqueous solutions.}

220 Media inoculated with G20 experienced changes in aqueous phase chemistry that were 221 different from those incubated under sterile anaerobic conditions. The $\mathrm{pH}$ increased from 7.5 to

2228.3 in inoculated formate and acetate media, whereas it increased only slightly from 7.5 to 7.7 in 223 uninoculated media (Table 2). The pH decreased from 7.5 to 6.9 in the inoculated lactate

224 medium but increased from 7.5 to 8.0 when the medium was incubated under sterile conditions.

225 The results demonstrate that the $\mathrm{pH}$ change is a function of the electron donor used for sulfate 226 reduction, i.e. that lactate utilization decreases the $\mathrm{pH}$, whereas formate and hydrogen utilization 227 increases the $\mathrm{pH}$.

228 Sulfate reduction with some electron donors also affected the precipitation of Ca and Mg 229 through processes that could not be accounted for by abiotic reactions. In formate and acetate 230 media, the Ca concentration decreased by $5.8 \mathrm{mM}$ (67\%) and $1.9 \mathrm{mM}$ (22\%), respectively, after 23110 mo incubation, whereas no change in Ca concentration was observed in the lactate medium 232 after incubation under sulfate-reducing conditions (Table 2, SI Fig 1a). The Ca decrease in 233 formate and acetate media could not be accounted for by abiotic reactions: Ca decreased by only $234 \quad 0.8 \mathrm{mM}(9 \%)$ in the sterile formate medium and not at all in the sterile acetate medium after 235 incubation for the same period of time (SI Fig. 1a). The Mg concentration decreased by $1.2 \mathrm{mM}$

236 (2.3\%) and $3.2 \mathrm{mM}(5.9 \%)$ in the formate and acetate media, respectively, after $10 \mathrm{mo}$

237 incubation under sulfate-reducing conditions (SI Fig. 1b). Since the Mg concentration did not 238 decrease in the sterile formate medium, it is unlikely that abiotic reactions were responsible for 239 the decrease during sulfate reduction (SI Fig. 1b). By contrast, the decrease in Mg concentration 240 in the sterile acetate medium (3.5 mM, 6.5\%) was similar to that observed in the inoculated 241 medium, suggesting that abiotic reactions may account for the decrease during sulfate reduction 
242 (SI Fig 1b). As in the case of Ca, the Mg concentration in the lactate medium changed little

243 during incubation under either biotic ( $0.9 \mathrm{mM}, 1.7 \%$ decrease) or abiotic conditions (1.8 mM,

244 3.2\% decrease) (SI Fig. 1b).

245 Sulfate reduction with some electron donors also affected alkalinity in ways that could not be 246 accounted for by abiotic reactions. Following incubation, total alkalinity (TA) was higher in the 247 inoculated than in the sterile formate medium (Table 2). By contrast, the TA was slightly lower 248 after incubation of the inoculated than the sterile acetate medium (Table 2). These differences, 249 albeit based on a single set of data, are consistent with results of other aqueous phase 250 constituents which also varied depending on the electron donors used for sulfate reduction.

\section{$251 \quad 3.2$ Solid characterization.}

252 All sterile media contained a trace of white solids prior to incubation under sterile anaerobic 253 or sulfate-reducing conditions. A black precipitate appeared on the nail in all media inoculated 254 with G20, indicating sulfide production and conversion to iron sulfide. Over the remaining 10-

255 mo incubation period, the black precipitate accumulated throughout the inoculated lactate 256 medium, but never extended beyond the nail in the inoculated formate and acetate media. No 257 black precipitate appeared in media incubated for 10 mo under sterile conditions, indicating that 258 sulfide production in the inoculated media was the result of biotic rather than abiotic reactions. 259 During incubation, white solids continued to accumulate in the inoculated formate and acetate 260 media but not in the inoculated lactate medium or any of the sterile media.

261 XRD results showed that the solids formed under the different conditions had different 262 mineral compositions but replicates contained the same mineral phases (new Table 3). Figure 1 263 shows a typical XRD pattern from solids formed under each condition. The solids formed in the 264 inoculated formate medium (1_38 and 2_104) consisted primarily of monohydrocalcite (MHC) 
and a small quantity of calcite (new Fig. 1a, Table 2). The trace of white solids recovered from

266 the formate medium incubated under sterile conditions (1_47) consisted of amorphous material, 267 aragonite $\left(\mathrm{CaCO}_{3}\right)$, $\mathrm{Mg}$-calcite $\left(\mathrm{Mg}_{0.15} \mathrm{Ca}_{0.85} \mathrm{CO}_{3}\right)$ and quartz $\left(\mathrm{SiO}_{2}\right)$ (new Fig. 1b, Table 2). Thus, 268 the minerals formed during bacterial sulfate reduction with formate differed from those that 269 formed in the medium incubated under abiotic conditions.

270 The white solids that formed in the acetate medium after sulfate reduction with hydrogen 271 (1_103 and 2_35) consisted of crystalline Mg-phosphate hydrate $\left[\mathrm{Mg}_{3}\left(\mathrm{PO}_{4}\right)_{2} \cdot 10 \mathrm{H}_{2} \mathrm{O}\right]$, baricite $272\left[\left(\mathrm{Mg}, \mathrm{Fe}^{2+}\right)_{3}\left(\mathrm{PO}_{4}\right)_{2} \cdot 8 \mathrm{H}_{2} \mathrm{O}\right]$, calcite and $\mathrm{S}^{\mathrm{o}}$ (new Fig. 1c, new Table 3). The trace of white solids 273 recovered from the incubated sterile acetate medium (1_105 and 2_44) was comprised primarily 274 amorphous material with a small amount of calcite (Fig. 1d, Table 2). Thus, calcite was favored 275 in the acetate medium in the presence and absence of sulfate reduction with hydrogen.

276 A small greigite $\left(\mathrm{Fe}_{3} \mathrm{~S}_{4}\right)$ and $\mathrm{S}^{\mathrm{o}}$ were detected after sulfate reduction with lactate (1_41 and 277 2_102), whereas no mineral phase was detected in the sterile lactate medium (1_101 and 2_50) 278 (Fig. 1e and 1f, Table 2). The solid phase formed under these conditions was dominated by 279 amorphous material (Table 2).

280 SEM revealed that the solids from the inoculated formate medium were dominated by 281 rhombohedral crystals in the size range of 2-7 $\mu \mathrm{m}$ (Fig. 2a). EDS analysis of samples containing 282 only the crystals (1_38-7 \& -8, 1_38-1-A \& -8-A, 1_38-15-1 \& -2, and 1_38_3-2) indicated that 283 they consisted of C, O, Ca, with possibly traces of Mg in some instances (SI Table 2). The 284 averaged $\mathrm{Ca}: \mathrm{C}: \mathrm{O}$ ratio of these samples was $0.7: 1: 3.2$, typical of calcium carbonates. Small 285 spheres of uniform size ( 0.2 $\mu \mathrm{m}$ in diameter) were also observed in some samples (1_38-1-B, 286 1_38-3 through 1_38-6, 1_38-7-A through -D and 1_38-10 through 12) as aggregations or 287 chains adjacent to the rhombohedral crystals (Fig. 2b). The spheres have a rough surface texture 
and appear to be hollow based on the voids observed within a few of the spheres that were

289 broken or had holes in their surface (Fig. 2c \& 2d). Since the spheres were smaller than the 290 smallest interaction volume $\left(\sim 6-9 \mu^{3}\right)$ sampled by EDS (Kanaya and Okayama, 1972), their

291 elemental composition was assessed by focusing the electron beam on aggregations of spheres, 292 which together with the crystals made up the total sample volume. All sampled volumes with

293 both spheres and crystals contained mostly Ca, C and O, with Mg, often Fe, occasionally P and 294 possibly a trace of $\mathrm{Na}$, Si and $\mathrm{Cl}$ present (SI Table 2). However, the atomic percentages did not 295 match any known stoichiometric minerals.

296 Extensive SEM of solids recovered from the formate medium incubated under sterile 297 conditions revealed no morphologies characteristic of the aragonite or Mg-calcite detected by 298 XRD. Presumably, these minerals were obscured by the large amount of amorphous material 299 present (Table 2). However, many of the samples contained hollow spheres with a smooth 300 surface and a wider range of sizes (0.4-2.5 $\mu \mathrm{m}$ dia.) than the spheres observed in the inoculated 301 medium (Fig. 3a and 3b). EDS indicated that all sampled volumes with spheres contained mostly $302 \mathrm{C}$ and O, lesser amounts of Mg, Ca, Fe, P and possibly a trace of Na and Si (SI Table 2). The 303 atomic percentages did not match any known stoichiometric minerals, presumably due to 304 interference from amorphous material present in the samples.

305 The amorphous material which dominated the solids in the incubated sterile acetate medium 306 and the inoculated lactate medium also obscured the calcite, greigite and sulfur detect in the 307 respective media by XRD. SEM examination of solids from inoculated acetate medium revealed 308 crystals with morphologies corresponding to the phosphate minerals detected by XRD (data not 309 shown), but were not further characterized. 
Since MHC and calcite do not typically coexist under conditions in which microorganism are

311 present (Davies et al., 1977; Fischbeck and Müller, 1971), the solids from the inoculated formate

312 medium were examined further by EMPA to learn more about the composition of these

313 polymorphs. The $\mathrm{CaO}$ content varied from 43.5 to $46.0 \mathrm{wt} \%$ in some samples (1_38-1 and

314 2_104-1 to -5 ) and from 55.2 to $56.4 \mathrm{wt} \%$ in other samples (1_ 38-2 to -5) (Table 3). MgO, FeO,

$315 \mathrm{Na}_{2} \mathrm{O}, \mathrm{P}_{2} \mathrm{O}_{5}, \mathrm{SrO}$ and $\mathrm{SO}_{3}$ were present in minor or trace amounts. The total amount of oxides

316 range from 46.2 to $61.8 \mathrm{wt} \%$. It was assumed that $\mathrm{CO}_{2}$ and $\mathrm{CO}_{2}$ plus $\mathrm{H}_{2} \mathrm{O}$ accounted for the

317 balance of $\mathrm{C}$ and $\mathrm{O}$ for calcite and MHC, respectively, since $\mathrm{C}$ and $\mathrm{O}$ were not determined by

318 EMPA. The calculated atomic percentages of $\mathrm{Ca}$ and $\mathrm{CO}_{2}$ and $\mathrm{Ca}$ and $\left(\mathrm{CO}_{2}+\mathrm{H}_{2} \mathrm{O}\right)$ correspond

319 to that of stoichiometric calcite and MHC, respectively (Table 3). The slightly positive and

320 negative percent relative error for the atomic percentage of Ca indicates that the minerals may

321 contain trace of $\mathrm{Mg}(<0.01 \mathrm{~mol} \%)$ and some other elements but still possess close to the ideal Ca

322 stoichiometry for MHC and calcite, respectively, thus supporting the XRD results that both of

323 these calcium carbonate polymorphs formed during sulfate reduction with formate.

324 In summary, bacterial sulfate reduction promoted precipitation of minerals different from

325 those which formed in sterile medium. The use of different electron donors for sulfate reduction

326 favored the precipitation of different minerals: carbonates when formate served as electron

327 donor, predominantly phosphates and a small amount of carbonate when hydrogen served as

328 electron donor and sulfur-containing minerals when lactate served as electron acceptor.

\section{$329 \quad 3.3$ Modeling of experiments.}

330 The predictions of the geochemical model generally agreed with experimental data, assuming

331 the sulfate-reducing reactions presented in equations 1-3. The trace amount of white precipitates

332 in all media prior to incubation is consistent with the modeled prediction of slight supersaturation 
333 with respect to calcium phosphate $\left[\mathrm{Ca}_{3}\left(\mathrm{PO}_{4}\right)_{2}\right]$, hydroxyapatite $\left[\mathrm{Ca}_{10}\left(\mathrm{PO}_{4}\right)_{6}(\mathrm{OH})_{2}\right]$, dolomite

$334\left[\mathrm{CaMg}\left(\mathrm{CO}_{3}\right)_{2}\right]$, and calcite $\left(\mathrm{CaCO}_{3}\right)$ based on the concentrations of media components (SI Fig.

335 2). The predicted $\mathrm{pH}$ increase from 7.5 to 8.7 and from 7.5 to 8.4 upon reduction of all the sulfate

336 to sulfide in the formate and acetate media, respectively, was similar to the increase measured in

337 the experiments (SI Fig. 3). Correspondingly, the $\mathrm{pH}$ decrease predicted by the model upon

338 reduction of sulfate in the lactate medium reflected the measured decrease after incubation of the

339 inoculated medium (SI Fig. 3). Thus, the changes in $\mathrm{pH}$ observed after incubation of all

340 inoculated media are consistent with those attributable to sulfate reduction according to

341 equations 1-3.

342 Model predictions of changes in the SI of various mineral phases during sulfate reduction

343 with different electron donors were generally consistent with the behavior of $\mathrm{Ca}$ and $\mathrm{Mg}$ in the

344 experiment. When the model reacted the $5.8 \mathrm{mM}$ of Ca lost from solution during the 10-mo

345 incubation with a stoichiometric amount of carbonate under sulfate-reducing conditions using

346 formate as electron donor, calcite and MHC were supersaturated after $10 \%$ of the sulfate in the

347 medium had been reduced (SI Fig. 2). When the model reacted the experimental Ca decrease of

$3481.9 \mathrm{mM}$ with stoichiometric amounts of phosphate and hydroxide to form hydroxyapatite under

349 sulfate-reducing conditions with hydrogen as electron donor, the SI of hydroxyapatite was

350 predicted to be lower after all the sulfate was consumed than before sulfate reduction (SI Fig. 2).

351 The predicted decrease in the SI of hydroxyapatite during later stages of sulfate reduction agrees

352 with the experimental result: its absence from the medium after incubation. The experimental

353 detection of $\mathrm{Mg}_{3}\left(\mathrm{PO}_{4}\right)_{2}$ also agrees with the model prediction of supersaturation under these

354 conditions (SI Fig. 2). 
A smaller increase in the SI of carbonates was predicted during sulfate reduction with

356 hydrogen compared to formate (SI Fig. 2), agreeing with XRD results that carbonate minerals

357 contributed a smaller fraction of the solids formed with hydrogen than formate as electron donor

358 (Table 2). The extent to which various minerals precipitated during sulfate reduction with the

359 different electron donors generally followed model predictions. The smaller increase in SI

360 predicted for carbonates during sulfate reduction with hydrogen than with formate (SI Fig. 2) is

361 accordant with XRD results indicating that carbonate minerals contributed a smaller fraction of

362 the solids formed under the former than under the latter conditions (Table 2). Similarly, the

363 model predicted a decrease in the $\mathrm{SI}$ of $\mathrm{Ca}_{3}\left(\mathrm{PO}_{4}\right)_{2}$ and only small changes in the SI of other

364 phosphate and carbonate minerals after sulfate reduction with lactate (SI Fig. 2); consistent with

365 the absence of phosphate and carbonate minerals in the experiment.

366 The model also predicted that among the three electron donors used in this study, sulfate

367 reduction with formate produced the largest increase in carbonate alkalinity (CA) after all sulfate

368 was reduced. The experimental TA results supported this prediction. The model predicted a

369 small increase in CA after reduction of all sulfate when hydrogen served as electron donor;

370 however, the TA decreased slightly under these experimental conditions. Nevertheless, the

371 model generally supported the experimental data indicating that mineral precipitation is

372 influenced by the electron donor, according to changes to fluid chemistry based on the reactions

373 in equations $1-3$.

\section{4. DISCUSSION}

\section{$375 \quad 4.1$ Abiotic reactions among medium components}

376 All but one of the media used in the study supported mineral formation under sterile

377 anaerobic conditions. The formation of aragonite and Mg-calcite but not calcite in the formate 
medium is consistent with other studies showing that high initial sulfate and phosphate

379 concentrations, high $\mathrm{Mg} / \mathrm{Ca}$ ratios and low calcite supersaturation favor the formation of other

380 polymorphs of calcium carbonate over calcite (Berner, 1975; De Choudens-Sanchez and

381 Gonzalez, 2009; Gallagher et al., 2013; Mucci and Morse, 1983; Rivadeneyra et al., 1985;

382 Rodriguez-Blanco et al., 2014; Taylor, 1975; Tracy et al., 1998). The increase in the Mg/Ca ratio

383 observed during incubation likely contributed to calcite inhibition. Aragonite and Mg-calcites are

384 common carbonate minerals at marine cold seeps (Greinert and Derkachev, 2004; Han et al.,

385 2008; Han et al., 2004). Thus, in spite of the unnaturally high concentrations of ammonia,

386 phosphate and formate in the medium, the incubation conditions were sufficiently similar to

387 those in marine cold seep sediments to favor precipitation of the same dominant mineral phases.

388 While the formation of these minerals at marine cold seeps has been attributed to the anaerobic

389 oxidation of methane by microorganisms (Boetius et al., 2000; Greinert and Derkachev, 2004;

390 Han et al., 2008; Han et al., 2004; Paull et al., 1992; Suess et al., 1999), the results here suggest

391 that they can also form abiotically in nutrient-enriched pore water medium containing formate.

392 The formation of calcite when acetate replaced formate in the medium suggests that the

393 initial high sulfate and phosphate concentrations, high $\mathrm{Mg} / \mathrm{Ca}$ ratio and low calcite

394 supersaturation were not sufficient to inhibit its formation under these conditions. Since Mg is

395 known to inhibit calcite formation (Bischoff and Fyfe, 1968; Cölfen, 2003; De Choudens-

396 Sanchez and Gonzalez, 2009; Morse et al., 2007), the precipitation of Mg and accompanying

397 decrease in the $\mathrm{Mg} / \mathrm{Ca}$ ratio during incubation of the acetate medium likely allowed calcite to

398 form under these conditions. By contrast, the inhibition of Ca and Mg precipitation by lactate

399 likely prevented mineral formation under sterile conditions when it replaced formate or acetate in

400 the medium. 
The difference in removal of $\mathrm{Ca}$ and $\mathrm{Mg}$ from sterile anaerobic formate, acetate and lactate

media may reflect variations in the extent to which $\mathrm{Ca}$ and $\mathrm{Mg}$ interact with these organic compounds, since the composition of the media differed only with respect these components.

The formation of soluble complexes changes the solution activity of $\mathrm{Mg}$ and $\mathrm{Ca}$ and thus the SI of minerals containing these cations (Fein, 1991). According to the geochemical model, formate complexed more $\mathrm{Ca}$ and $\mathrm{Mg}$ than did lactate and acetate, indicating that higher concentrations and saturation values are predicted for $\mathrm{Ca}$ and $\mathrm{Mg}$ minerals in the acetate and lactate media than in the formate medium (SI Table 2). Thus, more Ca and Mg should have precipitated in the lactate and acetate media than in the formate medium, contrary to what was observed experimentally. The model also indicated that formate complexed more Ca than Mg, favoring precipitation of Mg over Ca (SI Table 2), again contradicting the experimental results. The model further indicated that acetate complexed more Mg than Ca (SI Table 2), which should have favored an increase in the $\mathrm{Mg} / \mathrm{Ca}$ ratio and inhibition of calcite, in contrast to what was observed in the experiment. Thus, the predicted complexation of Ca and Mg by acetate cannot account for alleviation of calcite inhibition in acetate medium. Instead, the results suggest that processes other than the complexation reactions considered here controlled the abiotic precipitation of Ca and Mg in formate, acetate and lactate media. Nevertheless, the results are consistent with those of other studies indicating that the type of carbonate mineral formed in various media depends on the organic constituents present in solution (Berner, 1975; Kitano and Hood, 1965; Mann et al., 1990; Meldrum and Hyde, 2001; Suess, 1970; Zullig and Morse, 1988).

\subsection{Changes in medium composition during bacterial sulfate reduction}

The observed increase in medium $\mathrm{pH}$ during sulfate reduction with formate and hydrogen results from the consumption of protons during the oxidation of these electron donors, the 
424 removal of sulfate from solution and the removal of hydrogen sulfide by the iron in the medium 425 (Ben-Yaakov, 1973; Castanier et al., 1999; Hockin and Gadd, 2007; Stoessell, 1992; Thauer et 426 al., 2009; Wright, 1999). The decrease in medium $\mathrm{pH}$ when lactate serves as electron donor has 427 been attributed to the formation of acetic acid and the production and accumulation of protons in 428 the medium after sulfate becomes limiting (Birnbaum and Wireman, 1984; Pankhania et al., 429 1988; Plugge et al., 2011). In the present study, the pH of the medium decreased even though 430 protons produced by the reactions above were consumed through oxidation of the nail to $\mathrm{Fe}$ (II) 431 during the formation of iron sulfide (Castanier et al., 1999; Enning and Garrelfs, 2014).

432 The increase in TA during sulfate reduction with formate was consistent with model 433 predictions of an increase in CA and with the results of others (Gallagher et al., 2012). Alkalinity 434 increases when DIC is produced from the oxidation of organic electron donors and when sulfate 435 is removed during sulfate reduction (Abd-le-Malek and Rizk, 1963; Larowe et al., 2008; Meister, 436 2013). According to Equation 1, DIC is produced during formate oxidation. The slight decrease 437 in TA with hydrogen as electron donor in acetate medium likely reflects consumption of more 438 alkalinity from growth-related removal of DIC from solution (supplied in the form of carbonate 439 medium components) than that generated by sulfate removal. The discrepancy between the slight 440 decrease in TA of the medium observed under these conditions and the slight increase in CA 441 predicted by the model likely results from the model not accounting for cell growth-related DIC 442 consumption as neither growth nor DIC concentration were measured in the study.

443 The changes in calcite SI (SI calcite $_{\text {) }}$ during sulfate reduction with formate, hydrogen or lactate 444 that were predicted by the model followed the trends observed in other modeling studies 445 (Gallagher et al., 2012). The higher SI calcite predicted during sulfate reduction with formate than 446 with hydrogen likely reflected the difference in TA since $\mathrm{pH}$ changes were similar under both 
447 conditions. The decrease in $\mathrm{SI}_{\text {calcite }}$ predicted at the onset of sulfate reduction with lactate is

448 thought to result from acid production, while the return to near initial values later in the

449 incubation has been attributed to bicarbonate production (Gallagher et al., 2012).

$450 \quad$ 4.3 Mineral precipitation during sulfate reduction

451 Although the model indicated that dolomite, $\mathrm{Ca}_{3}\left(\mathrm{PO}_{4}\right)_{2}, \mathrm{Ca}_{4}\left(\mathrm{PO}_{4}\right)_{3} \cdot 3 \mathrm{H}_{2} \mathrm{O}, \mathrm{Mg}_{3}\left(\mathrm{PO}_{4}\right)_{2}, \mathrm{MHC}$

452 and calcite were all supersaturated during sulfate reduction in formate medium, MHC and a

453 small amount of calcite were the only mineral phases detected under these conditions. MHC

454 typically precipitates as a secondary mineral in the presence of microorganisms (Davies et al.,

455 1977; Rivadeneyra et al., 1998; Rivadeneyra et al., 1993; Rivadeneyra et al., 2004). Small

456 quantities of MHC have been reported to precipitate with nonstoichiometric dolomite during

457 sulfate reduction with formate in a medium simulating conditions of a hypersaline lagoon

458 (Warthmann et al., 2000). However, this is the first time the precipitation of MHC was favored

459 over other $\mathrm{CaCO}_{3}$ polymorphs under sulfate-reducing conditions.

460 While MHC and calcite have similar structures, both belonging to the rhombohedral subclass

461 (trigonal) of the hexagonal system (Dahl and Buchardt, 2006; Roberts et al., 1990), the large

462 rhombohedral crystals seen by SEM dominating the solid phase in the inoculated formate

463 medium are likely MHC because it contributed the bulk (96\%) of the crystalline material in the

464 sample. The low Mg content of the large MHC crystals observed here suggests that they were at

465 an advanced stage of development since $\mathrm{Mg}$ is released during the maturation process

466 (Rodriguez-Blanco et al., 2014). While the transformation of metastable MHC to calcite has been

467 described under abiotic conditions (Liu et al., 2013), investigation of this process under bacterial

468 sulfate-reducing conditions here was beyond the scope of the present study. 
MHC typically precipitates with other carbonates such as Mg-calcite, aragonite, Ca-rich dolomite, hydromagnesite and nesquehonite under conditions of calcite inhibition (Broughton,

471 1972; Fischbeck and Müller, 1971; Nishiyama et al., 2013; Rodriguez-Blanco et al., 2014;

472 Taylor, 1975; Warthmann et al., 2000). The increase in TA and pH during sulfate reduction with 473 formate, conditions which are known to favor carbonate precipitation (Braissant et al., 2003;

474 Davies et al., 1977; Ganendra et al., 2014; Hammes and Verstraete, 2002; Meister, 2013; Taylor,

475 1975; Warthmann et al., 2000), likely favored MHC formation in the medium. The importance of 476 the TA increase to MHC formation was evident since the mineral did not form during sulfate 477 reduction with hydrogen in acetate medium which produced in a similar increase in pH without 478 an accompanying increase in TA.

479 The high TA achieved during sulfate reduction in the formate medium may also have 480 inhibited phosphate precipitation as shown in previous studies (Ferguson et al., 1973). Thus, 481 products of electron donor oxidation formed during bacterial sulfate reduction control the 482 precipitation of phosphate as well as carbonate minerals through their influence on alkalinity. 483 The inhibition of phosphate precipitation by high TA, the inhibition of calcite and aragonite by 484 phosphate and organic compounds (Dahl and Buchardt, 2006), and the enhancement of 485 phosphate inhibition of calcite and aragonite by sulfate removal (Burton, 1993) all likely favored 486 MHC formation during sulfate reduction with formate. The unnaturally high phosphate 487 concentration used to promote SRB growth in the present study may therefore have favored 488 MHC formation over aragonite and Mg-calcite, the polymorphs which typically dominate 489 carbonate deposits at marine cold seeps.

490 Although MHC has not been found at marine cold seeps, it is a common mineral (up to 55\%) 491 in debris fragments from submarine ikaite $\left(\mathrm{CaCO}_{3} \cdot 6 \mathrm{H}_{2} \mathrm{O}\right)$ tufa columns in the marine Ikka fjord 
492 in southwestern Greenland (Dahl and Buchardt, 2006). In this environment MHC is thought to be

493 a transitional diagenetic phase in the recrystallization of ikaite to calcite, similar to glendonite, an

494 ikaite pseudomorph found at marine cold seeps (Greinert and Derkachev, 2004). The conditions

495 which favored MHC formation in the fjord system (high phosphate, alkalinity and $\mathrm{Mg} / \mathrm{Ca}$ ratio

496 and low sulfate in a confined pore water system) are similar to those which favored its formation

497 in the present study. Thus, bacterial sulfate reduction with formate has the potential to establish

498 conditions favoring MHC formation in marine systems where ikaite, high phosphate

499 concentrations and high $\mathrm{Mg} / \mathrm{Ca}$ ratios exist.

500 The precipitation of phosphate minerals during microbial sulfate reduction has been

501 attributed to the high concentration of phosphate in the cultivation medium to promote growth of

502 SRB (Gallagher et al., 2013). Although the high phosphate concentration likely favored the

503 precipitation of phosphate minerals during sulfate reduction in the acetate medium, other factors

504 also contributed to their precipitation under these conditions since no phosphate minerals

505 precipitated during sulfate reduction in the formate or lactate media, which contained the same

506 initial phosphate concentrations. The slight decrease in TA and presumed consumption of DIC as

507 a carbon source for growth of G20, which did not occur during sulfate reduction in formate and

508 lactate media, also favored phosphate mineral formation in the acetate medium. Indeed,

509 preliminary experiments indicated that the white solids, including phosphate minerals, did not

510 accumulate during sulfate reduction with hydrogen unless acetate was present in the medium to

511 support cell growth.

512 Although not measured, the phosphate concentration would have decreased during sulfate

513 reduction in the acetate medium as a result of phosphate mineral formation. Since calcite growth

514 is affected by phosphate concentration (Burton, 1993; Burton and Walter, 1990; Reddy, 1977), 
515 precipitation of phosphate may have alleviated calcite inhibition even though the accompanying

516 increase in the $\mathrm{Mg} / \mathrm{Ca}$ ratio from 6.6 to 8.1 favored inhibition. The results are consistent with

517 those of previous studies indicating that multiple factors often contribute to calcite precipitation

518 (De Choudens-Sanchez and Gonzalez, 2009; Fernandez-Diaz et al., 1996; Given and Wilkinson, 519 1985).

520 Greigite and sulfur were the only minerals that precipitated during sulfate reduction with

521 lactate as electron donor. These phases likely occurred instead of carbonate minerals because of

522 the reduction in pH (Abbona et al., 1982; Birnbaum and Wireman, 1984; Stoessell, 1992). While

523 the SI of greigite was not modeled here, the $\mathrm{pH}$ change predicted by the model mimicked the $\mathrm{pH}$

524 change that occurred in the lactate medium. The formation of iron sulfides at low $\mathrm{pH}$ during

525 sulfate reduction with lactate and at high $\mathrm{pH}$ during sulfate reduction with formate and hydrogen 526 agrees with other studies (Donald and Southam, 1999). Greigite and elemental sulfur are among

527 the sulfur minerals found at marine cold seeps within or near the SMTZ where their formation is

528 thought to result from the activities of SRB (Lin et al., 2015; Wrede et al., 2013).

\section{$529 \quad 4.4$ Conclusions}

530 The findings reported here show that bacterial sulfate reduction with different electron 531 donors results in the formation of different minerals in response to chemical changes in the 532 medium associated with the consumption and production of reactants and products of the redox 533 reactions. MHC and calcite formed during the oxidation of formate, Mg-phosphates, baricite,

534 calcite and elemental sulfur formed during the oxidation of hydrogen and greigite and elemental

535 sulfur formed during the oxidation of lactate. The results support a growing body of evidence 536 that the types of minerals formed in the presence of microorganisms are influenced by the 537 metabolic pathway used for energy production and growth (Visscher and Stolz, 2005). Thus, the 
538 MHC observed in a coastal fjord system may have formed through sulfate reduction with

539 formate since some of the conditions in that environment resemble those generated by this

540 process in the present study. The inability to promote formation of the common carbonate

541 minerals found at marine cold seeps in the studies reported here may have been due to the high

542 phosphate concentration used in the experiments and the current uncertainty of the electron

543 donor used by SRB inhabiting the SMTZ.

\section{Acknowledgments}

545 This study was funded by National Natural Science Foundation of China (No. 40976040),

546973 Program (2009CB21950607), Zhejiang Provincial National Natural Science Foundation of

547 China (No. R5110215), and the US Department of Energy (No. DE-FG02-13ER86571). Funding

548 for the establishment and operation of the Environmental and Biofilm Mass Spectrometry

549 Facility at Montana State University (MSU) was provided by the Defense University Research

550 Instrumentation Program (DURIP, Contract Number W911NF0510255) and the MSU Thermal

551 Biology Institute from the NASA Exobiology Program (Project NAG5-8807). We would like to

552 thank Prof. Erwin Suess for his constructive discussions.

\section{References}

555 Abbona, F., Lundagger Madsen, H.E., Boistelle, R., 1982. Crystallization of two magnesium

556 phosphates, struvite and newberyite: Effect of $\mathrm{pH}$ and concentration. J. Cryst. Growth, 557 57(1): 6-14.

558 Abd-le-Malek, Y., Rizk, S.G., 1963. Bacterial sulphate reduction and the development of

559 alkalinity. I. Experiments with synthetic media. J. Appl. Bacteriol., 26(1): 7-13. 
Alsenz, H. et al., 2015. Geochemical evidence for the link between sulfate reduction, sulfide oxidation and phosphate accumulation in a late cretaceous upwelling system. Geochem. Trans., 16: 1-13.

Arning, E.T., Birgel, D., Brunner, B., Peckmann, J., 2009. Bacterial formation of phosphatic

Atlas, R.M., 2004. Handbook of Microbiological Media. CRC Press, Boca Raton, FL.

Bavendamm, W., 1932. Die mikrobiologische Kalkfallung in der tropischen See. Arkiv. Mikrobiol., 3: 205-276.

Ben-Yaakov, S., 1973. pH buffering of pore water of recent anoxic marine sediments. Limnol. Oceanogr., 18(1): 86-94.

Berner, R.A., 1975. The role of magnesium in the crystal growth of calcite and aragonite from sea water. Geochim. Cosmochim. Acta, 39(4): 489-504.

Birnbaum, S.J., Wireman, J.W., 1984. Bacterial sulfate reduction and pH: implications for early diagenesis. Chem. Geol., 43(1-2): 143-149.

Bischoff, J.L., Fyfe, W.S., 1968. Catalysis, inhibition, and the calcite-aragonite problem. Am. J. Sci., 266(2): 65-79.

Boetius, A. et al., 2000. A marine microbial consortium apparently mediating anaerobic oxidation of methane. Nature, 407(6804): 623-626.

Bosak, T., Newman, D.K., 2003. Microbial nucleation of carbonate on bacterial nanoglobules. Geology, 31(7): 577-580.

Bosak, T., Newman, D.K., 2005. Microbial kinetic controls on calcite morphology in supersaturated solutions. J. Sed. Res., 75(2): 190-199. 
Braissant, O., Cailleau, G., Dupraz, C., Verrecchia, A.P., 2003. Bacterially induced mineralization of calcium carbonate in terrestrial environments: The role of exopolysaccharides and amino acids. J. Sed. Res., 73: 485-490.

Breibart, M. et al., 2009. Metagenomic and stable isotope analysis of modern freshwater microbialites in Cuatro Cienegas, Mexico. Environ. Microbiol., 11(1): 16-34.

Broughton, P.L., 1972. Monohydrocalcite in speleothems: An alternative interpretation. Contrib. Mineral. Petrol., 36(2): 171-174.

Burton, E.A., 1993. Controls on marine carbonate cement mineralogy: review and reassessment. Chem. Geol., 105(1-3): 163-179.

Burton, E.A., Walter, L.M., 1990. The role of pH in phosphate inhibition of calcite and aragonite precipitation rates in seawater. Geochim. Cosmochim. Acta, 54(3): 797-808.

Castanier, S., Le Metayer-Levrel, G., Perthuisot, J.P., 1999. Ca-carbonates precipitation and limestone genesis-the microbiologists point of view. Sediment. Geol., 126(1-4): 9-23.

Cölfen, H., 2003. Precipitation of carbonates: recent progress in controlled production of complex shapes. Curr. Opin. Colloid Interface Sci., 8(1): 23-31.

Da Silva, S., Bernet, N., Delgenes, J.P., Moletta, R., 2000. Effect of culture conditions on the formation of struvite by Myхососcus xanthus. Chemosphere, 40(12): 1289-1296.

Dahl, K., Buchardt, B., 2006. Monohydrocalcite in the Arctic Ikka Fjord, SW Greenland: First Reported Marine Occurrence. J. Sed. Res., 76(3): 460-471.

Davies, P.J., Bubela, B., Ferguson, J., 1977. Simulation of carbonate diagenetic processes: formation of dolomite, huntite and monohydrocalcite by the reactions between nesquehonite and brine. Chem. Geol., 19(1-4): 187-214. 
604 De Choudens-Sanchez, V., Gonzalez, L.A., 2009. Calcite and aragonite precipitation under

605

606

607

608

609

610

611

612

613

614

615

616

617

618

619

620

621

622

623

624

625

626

controlled instantaneous supersaturation: elucidating the role of $\mathrm{CaCO}_{3}$ saturation state and Mg/Ca ratio on calcium carbonate polymorphism. J. Sed. Res., 79(6): 363-376.

Donald, R., Southam, G., 1999. Low temperature anaerobic bacterial diagenesis of ferrous monosulfide to pyrite. Geochim. Cosmochim. Acta, 63(13-14): 2019-2023.

Douglas, S., 2005. Mineralogical footprints of microbial life. Am. J. Sci., 305(6-8): 503-525.

Dupraz, C., Visscher, P.T., 2005. Microbial lithification in marine stromatolites and hypersaline mats. Trends Microbiol., 13(9): 429-438.

Enning, D., Garrelfs, J., 2014. Corrosion of iron by sulfate-reducing bacteria: New views of an old problem. Appl. Environ. Microbiol., 80(4): 1226-1236.

Fein, J.B., 1991. Experimental study of aluminum-, calcium-, and magnesium-acetate complexing at $80^{\circ} \mathrm{C}$. Geochim. Cosmochim. Acta, 55(4): 955-964.

Ferguson, J.F., Jenkins, D., Eastman, J., 1973. Calcium phosphate precipitation at slightly alkaline pH values. J. Wat. Pollut. Contr. Fed., 45(4): 620-631.

Fernandez-Diaz, L., Putnis, A., Prieto, M., Putnis, C.V., 1996. The role of magnesium in the crystallization of calcite and aragonite in a porous medium. J. Sed. Res., 66(3): 482-491.

Ferrer, M.R. et al., 1988. Calcium-carbonate formation by Deleya halophila - effect of salt concentration and incubation temperature. Geomicrobiol. J., 6(1): 49-57.

Fischbeck, R., Müller, G., 1971. Monohydrocalcite, hydromagnesite, nesquehonite, dolomite, aragonite, and calcite in speleothems of the Fränkische Schweiz, Western Germany. Contrib. Mineral. Petrol., 33(2): 87-92.

Gallagher, K.L., Braissant, O., Kading, T.J., Dupraz, C., Visscher, P.T., 2013. Phosphate-related artifacts in carbonate mineralization experiments. J. Sed. Res., 83(1): 37-49. 
627 Gallagher, K.L., Kading, T.J., Braissant, O., Dupraz, C., Visscher, P.T., 2012. Inside the

628 alkalinity engine: the role of electron donors in the organomineralization potential of

629 sulfate-reducing bacteria. Geobiology, 10(6): 518-530.

630 Ganendra, G. et al., 2014. Formate oxidation-driven calcium carbonate precipitation by

631 Methylocystis parvus OBBP. Appl. Environ. Microbiol., 80(15): 4659-4667.

632 Given, R.K., Wilkinson, B.H., 1985. Kinetic control of morphology, composition, and

633 mineralogy of abiotic sedimentary carbonates. J. Sed. Petrol., 55(1): 109-119.

634 Greenfield, L.J., 1963. Metabolism and concentration of calcium and magnesium and

635 precipitation of calcium carbonate by a marine bacterium. Ann. N.Y. Acad. Sci., 109: 23-

63645.

637 Greinert, J., Derkachev, A., 2004. Glendonites and methane-derived Mg-calcites in the Sea of

638 Okhotsk, eastern Siberia: implications of a venting-related ikaite/glendonite formation.

639 Mar. Geol., 204(1-2): 129-144.

640 Gunatilaka, A., Saleh, A., Al-Temeemi, A., Nassar, N., 1984. Occurrence of subtidal dolomite in

641 a hypersaline lagoon, Kuwait. Nature, 311(5985): 450-452.

642 Hammes, F., Verstraete, W., 2002. Key roles of pH and calcium metabolism in microbial

643 carbonate precipitation. Re/Views Environ. Sci. Bio/Technol., 1(1): 3-7.

644 Han, X. et al., 2008. Jiulong methane reef: Microbial mediation of seep carbonates in the South

645 China Sea. Mar. Geol., 249(3-4): 243-256.

646 Han, X., Suess, E., Sahling, H., Wallmann, K., 2004. Fluid venting activity on the Costa Rica

647 margin: new results from authigenic carbonates. Int. J. Earth Sci., 93(4): 596-611.

648 Hauser, L.J. et al., 2011. Complete genome sequence and updated annotation of Desulfovibrio

649 alaskensis G20. J. Bacteriol., 193(16): 4268-4269. 
Heuer, V.B., Pohlman, J.W., Torres, M.E., Elvert, M., Hinrichs, K., 2009. The stable carbon isotope biogeochemistry of acetate and other dissolved carbon species in deep subseafloor sediments at the northern Cascadia Margin. Geochim. Cosmochim. Acta 73: 3323-3336.

Hockin, S.L., Gadd, G.M., 2007. Bioremediation of metals and metalloids by precipitation and cellular binding. In: Barton, L.L., Hamilton, W.A. (Eds.), Sulfate-reducing bacteria. Cambridge University Press, Cambridge, pp. 405-434.

Joye, S.B. et al., 2004. The anaerobic oxidation of methane and sulfate reduction in sediments from Gulf of Mexico cold seeps. Chem. Geol., 205(3-4): 219-238.

Kanaya, K., Okayama, S., 1972. Penetration and energy-loss theory of electrons in solid targets. J. Phys. D: Appl. Phys., 5(1): 43-58.

Kendall, M.M. et al., 2007. Diversity of archaea in marine sediments from Skan Bay, Alaska, including cultivated methanogens,and description of Methanogenium boonei sp. nov. Appl. Environ. Microbiol., 73(2): 407-414.

Khosrovi, B., Macpherson, R., Miller, J.D.A., 1971. Some observations on growth and hydrogen uptake by Desulfovibrio vulgaris. Arch. Microbiol., 80(4): 324-337.

Kitano, Y., Hood, D.W., 1965. The influence of organic material on the polymorphic crystallization of calcium carbonate. Geochim. Cosmochim. Acta, 29(1): 29-41.

Krause, S. et al., 2012. Microbial nucleation of Mg-rich dolomite in exopolymeric substances under anoxic modern seawater salinity: New insights into an old enigma. Geology, 40(7): 587-590.

Labrenz, M. et al., 2000. Formation of sphalerite (ZnS) deposits in natural biofilms of sulfatereducing bacteria. Science, 290(5497): 1744-1747. 
673 Larowe, D.E., Dale, A.W., Regnier, P., 2008. A thermodynamic analysis of the anaerobic

674 oxidation of methane in marine sediments. Geobiology, 6(5): 436-449.

$675 \mathrm{Li}$, X. et al., 2009. A molybdopterin oxidoreductase is involved in $\mathrm{H}_{2}$ oxidation in Desulfovibrio 676 desulfuricans G20. J. Bacteriol., 191(8): 2675-2682.

677 Li, X., McInerney, M.J., Stahl, D.A., Krumholz, L.R., 2011. Metabolism of $\mathrm{H}_{2}$ by Desulfovibrio 678 alaskensis G20 during syntrophic growth on lactate. Microbiology, 157: 2912-2921.

679 Lin, Q. et al., 2015. Elemental sulfur in northern South China Sea sediments and its significance. $680 \quad$ Sci. China Ser. D., 58(12): 2271-2278.

681 Liu, R. et al., 2013. Crystallization and oriented attachment of monohydrocalcite and its crystalline phase transformation. Cryst. Eng. Comm., 15(3): 509-515.

683 Mann, S., Didymus, J.M., Sanderson, N.P., Heywood, B.R., 1990. Morphological influence of

McGlynn, S.E., Chadwick, G.L., Kempes, C.P., Orphan, V.J., 2015. Single cell activity reveals direct electron transfer in methanotrophic consortia. Nature, 526(7574): 531-535.

Meister, P., 2013. Two opposing effects of sulfate reduction on carbonate precipitation in normal marine, hypersaline, and alkaline environments. Geology, 41(4): 499-502.

690 Meldrum, F.C., Hyde, S.T., 2001. Morphological influence of magnesium and organic additives on the precipitation of calcite. J. Cryst. Growth, 231(4): 544-558.

692 Meulepas, R.J.W., Jagersma, C.G., Khadem, A.F., Stams, A.J.M., Lens, P.N.L., 2010. Effect of 693 methanogenic substrates on anaerobic oxidation of methane and sulfate reduction by an anaerobic methanotrophic enrichment. Appl. Microbiol. Biotechnol., 87(4): 1499-506. 
Morse, J.W., Arvidson, R.S., Luttge, A., 2007. Calcium carbonate formation and dissolution. Chem. Rev., 107(2): 342-381.

Mucci, A., Morse, J.W., 1983. The incorporation of $\mathrm{Mg}^{2+}$ and $\mathrm{Sr}^{2+}$ into calcite overgrowths: influences of growth rate and solution composition. Geochim. Cosmochim. Acta, 47(2): 217-233.

Nadson, G.A., 1928. Beitrag zur Kenntnis der bakteriogenen Kalkablagerungen. Arch. Hydrobiol., 19(1): 154-164.

Nishiyama, R., Munemoto, T., Fukushi, K., 2013. Formation condition of monohydrocalcite from $\mathrm{CaCl}_{2}-\mathrm{MgCl}_{2}-\mathrm{Na}_{2} \mathrm{CO}_{3}$ solutions. Geochim. Cosmochim. Acta, 100: 217-231.

Oyekola, O., van Hille, R.P., Harrison, S.T.L., 2009. Study of anaerobic lactate metabolism under biosulfidogenic conditions. Water Res., 43(14): 3345-3354.

Pankhania, I.P., Spormann, A.M., Hamilton, W.A., Thauer, R.K., 1988. Lactate conversion to acetate, $\mathrm{CO}_{2}$, and $\mathrm{H}_{2}$ in cell suspension of Desulfovibrio vulgaris (Marlburg): indications for the involvement of an energy driven reaction. Arch. Microbiol., 150(1): 26-31.

Paull, C.K., Chanton, J.P., Neumann, A.C., Coston, J.A., Martens, C.S., 1992. Indicators of methane-derived carbonates and chemosynthetic organic carbon deposits: Examples from the Florida Escarpment. Palaios, 7: 361-375.

Plugge, C.M., Zhang, W., Scholten, J.C.M., Stams, A.J.M., 2011. Metabolic flexibility of sulfate-reducing bacteria. Front. Microbiol., 2: 81.

Postgate, J.R., 1984. The sulphate reducing bacteria. Cambridge University Press, Cambridge \& London.

Price, M.N. et al., 2014. The genetic basis of energy conservation in the sulfate-reducing bacterium Desulfovibrio alaskensis G20. Front. Microbiol., 5. 
718 Reddy, M.M., 1977. Crystallization of calcium carbonate in the presence of trace concentrations

719 of phosphorus-containing anions: I. Inhibition by phosphate and glycerophosphate ions at $720 \quad \mathrm{pH} 8.8$ and $25^{\circ} \mathrm{C}$. J. Cryst. Growth, 41(2): 287-295.

721 Rivadeneyra, M.A., Delgado, G., Ramos-Cormenzana, A., Delgado, R., 1998. Biomineralization

724 Rivadeneyra, M.A. et al., 1993. Precipitation of carbonates by Bacillus sp. isolated from saline soils. Geomicrobiol. J., 11(3-4): 175-184.

Rivadeneyra, M.A., Martin-Algarra, A., Sanchez-Navas, A., Martin-Ramos, D., 2006. Carbonate and phosphate precipitation by Chromohalobacter marismortui. Geomicrobiol. J., 23(2): 89-101.

Rivadeneyra, M.A., Párraga, J., Delgado, R., Ramos-Cormenzana, A., Delgado, G., 2004.

Biomineralization of carbonates by Halobacillus trueperi in solid and liquid media with different salinities. FEMS Microbiol. Ecol., 48(1): 39-46.

Rivadeneyra, M.A., Perez-Garcia, I., Salmeron, V., Ramos-Cormenzana, A., 1985. Bacterial precipitation of calcium carbonate in presence of phosphate. Soil Biol. Biochem., 17(2): 171-172.

Roberts, W.L., Cambell, T.J., Rapp, G.R., JR., 1990. Encyclopedia of Minerals. Van Nostrand Reinhold, New York.

Rodriguez-Blanco, J.D., Shaw, S., Bots, P., Roncal-Herrero, T., Benning, L.G., 2014. The role of 739 Mg in the crystallization of monohydrocalcite. Geochim. Cosmochim. Acta, 127: 204220. 
Sanchez-Roman, M., Rivadeneyra, M.A., Vasconcelos, C., McKenzie, J.A., 2007. Biomineralization of carbonate and phosphate by moderately halophilic bacteria. FEMS Microbiol. Ecol., 61(2): 273-284.

743 Schulz, H.N., Schulz, H.D., 2005. Large sulfur bacteria and the formation of phosphorite. $744 \quad$ Science, 307(5708): 416-418.

745 Stoessell, R.K., 1992. Effects of sulfate reduction on $\mathrm{CaCO}_{3}$ dissolution and precipitation in 746 mixing-zone fluids. J. Sed. Petrol., 62(5): 873-880.

747 Suess, E., 1970. Interaction of organic compounds with calcium carbonate-I. Association 748

Suess, E., 2005. RV SONNE cruise report SO 177, Sino-German cooperative project, South China Sea Continental Margin: geological methane budget and environmental effects of methane emissions and gashydrates.

Suess, E., 2014. Marine cold seeps and their manifestations: geological control, biogeochemical criteria and environmental conditions. Int. J. Earth Sci. (Geol Rundsch) 103 (7): 18891916.

Suess, E. et al., 1999. Gas hydrate destabilization: enhanced dewatering, benthic material turnover and large methane plumes at the Cascadia convergent margin. Earth Planet. Sci. Lett., 170(1-2): 1-15.

Taylor, G.F., 1975. Occurrence of monohydrocalcite in 2 small lakes in southeast of South Australia. Am. Mineral., 60(7-8): 690-697.

Thauer, R.K., Stackebrandt, E., Hamilton, W.A., 2009. Energy metabolism and phylogenetic diversity of sulphate-reducing bacteria. In: Barton, L.L., Hamilton, W.A. (Eds.), Sulphate-reducing bacteria. Cambridge University Press, Cambridge, pp. 1-37. 
763 Tracy, S.L., Williams, D.A., Jennings, H.M., 1998. The growth of calcite spherulites from

764 solution: II. Kinetics of formation. J. Crystal Growth, 193(3): 382-388.

765 van Lith, Y., Warthmann, R., Vasconcelos, C., McKenzie, J.A., 2003. Microbial fossilization in

766 carbonate sediments: a result of the bacterial surface involvement in dolomite

767 precipitation. Sedimentology, 50(2): 237-245.

768 Vasconcelos, C., McKenzie, J.A., 1997. Microbial mediation of modern dolomite precipitation

769 and diagenesis under anoxic conditions (Lagoa Vermelha, Rio de Janeiro, Brazil). J. Sed.

$770 \quad$ Res., 67(3): 378-390.

771 Vasconcelos, C., McKenzie, J.A., Bernasconi, S., Grujic, D., Tien, A.J., 1995. Microbial

772 mediation as a possible mechanism for natural dolomite formation at low-temperatures.

$773 \quad$ Nature, 377(6546): 220-222.

774 Visscher, P.T. et al., 1998. Formation of lithified micritic laminae in modern marine

775 stromatolites (Bahamas): The role of sulfur cycling. Am. Mineral., 83(11-12): 1482-

7761493.

777 Visscher, P.T., Stolz, J.F., 2005. Microbial mats as bioreactors: populations, processes, and 778 products. Palaeogeogr. Palaeoecol., 219(1-2): 87-100.

779 Voordouw, G., 1995. The genus Desulfovibrio: The centennial. Appl. Environ. Microbiol., 61(8):

$780 \quad$ 2813-2819.

781 Wall, J.D., Rapp-Giles, B.J., Rousset, M., 1993. Characterization of a small plasmid from 782 Desulfovibrio desulfuricans and its use for shuttle vector construction. J. Bacteriol., 783 175(13): 4121-4128. 
784 Wang, S., Yan, W., Chen, Z., Zhang, N., Chen, H., 2014. Rare earth elements in cold seep carbonates from the southwestern Dongsha area, northern South China Sea. Mar. Petrol. Geol., 57: 482-493.

Warthmann, R., van Lith, Y., Vasconcelos, C., McKenzie, J.A., Karpoff, A.M., 2000. Bacterially induced dolomite precipitation in anoxic culture experiments. Geology, 28(12): 10911094.

Wegener, G., Krukenberg, V., Riedel, D., Tegetmeyer, H.E., Boetius, A., 2015. Intercellular wiring enables electron transfer between methanotrophic archaea and bacteria. Nature, 526(7574): 587-590.

Weimer, P.J., Van Kavelaar, M.J., Michel, C.B., Ng, T.K., 1988. Effect of phosphate on the corrosion of carbon steel and on the composition of corrosion products in two-stage continuous cultures of Desulfovibrio desulfuricans. Appl. Environ. Microbiol., 54(2): 386-396.

Wrede, C. et al., 2013. Deposition of biogenic iron minerals in a methane oxidizing microbial mat. Archaea, 2013: 102972.

Wright, D.T., 1997. An organogenic origin for widespread dolomite in the Cambrian Eilean Dubh Formation, Northwest Scotland. J. Sed. Res., 67(1): 54-64.

Wright, D.T., 1999. The role of sulfate-reducing bacteria and cyanobacteria in dolomite formation in distal ephemeral lakes of the Coorong region, South Australia. Sediment. Geol., 126(1-4): 147-157.

Zullig, J.J., Morse, J.W., 1988. Interaction of organic acids with carbonate mineral surfaces in seawater and related solutions: Fatty acid adsorption. Geochim. Cosmochim. Acta, 52(6): 1667-1678. 
Fig. 1
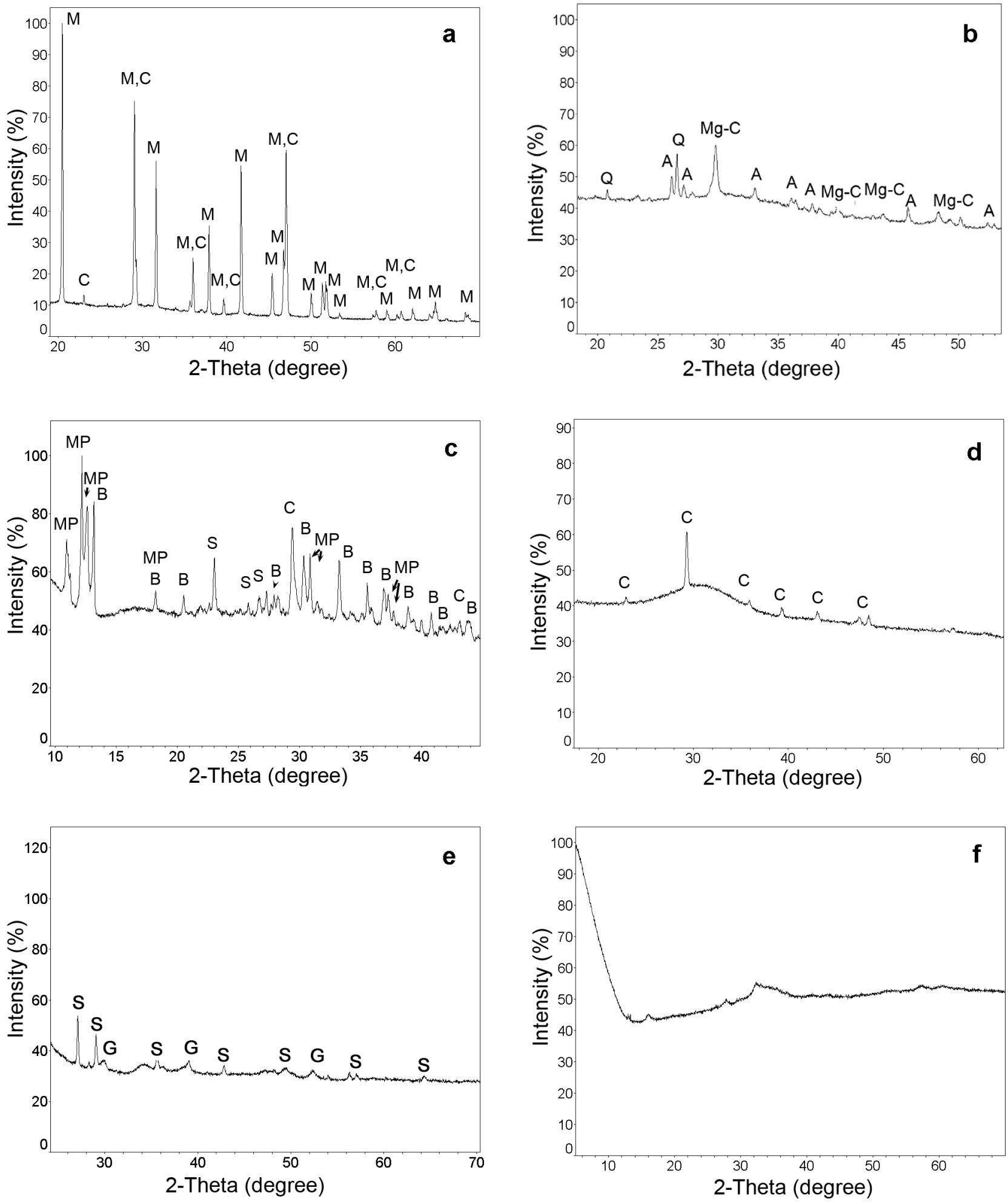


\section{Fig. 2}
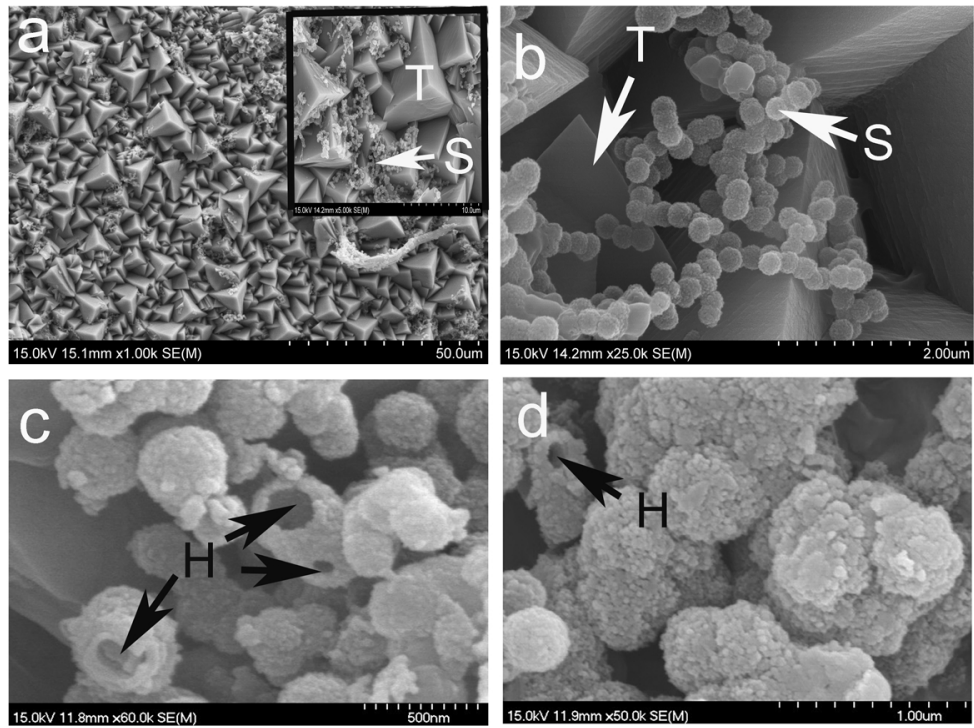
Table 1. Chemical composition of pore water from sediment core S0177-GC 10 recovered from a depth of 5.1 meters below the seafloor at a cold seep in the South China Sea and corresponding composition of the SRB cultivation medium.

\begin{tabular}{|c|c|c|c|c|c|c|}
\hline \multicolumn{2}{|c|}{ Sediment pore water $^{\mathrm{a}}$} & \multicolumn{5}{|c|}{ SRB cultivation medium } \\
\hline $\begin{array}{l}\text { Chemical } \\
\text { species }\end{array}$ & $\begin{array}{c}\text { Concentration } \\
\mathrm{mmol} / \mathrm{l}\end{array}$ & Chemical & $\begin{array}{l}\text { Concer } \\
\mathrm{mg} / \mathrm{l}\end{array}$ & $\begin{array}{l}\text { tration } \\
\mathrm{mmol} / \mathrm{l}\end{array}$ & $\begin{array}{l}\text { Chemical } \\
\text { species }\end{array}$ & $\begin{array}{c}\text { Concentration } \\
\mathrm{mmol} / \mathrm{l}\end{array}$ \\
\hline $\bar{I}$ & 0.024 & $\mathrm{I}$ & 3.05 & 0.024 & $\mathrm{I}$ & 0.024 \\
\hline $\mathrm{NH}_{4}$ & 0.079 & $\mathrm{NH}_{4} \mathrm{Cl}$ & 565.92 & 10.58 & $\mathrm{NH}_{4}{ }^{\mathrm{b}}$ & 10.58 \\
\hline $\mathrm{PO}_{4}$ & 0.014 & $\mathrm{Na}_{2} \mathrm{HPO}_{4}$ & 126.34 & 0.89 & $\mathrm{PO}_{4}{ }^{\mathrm{b}}$ & 0.89 \\
\hline $\mathrm{Cl}$ & 555.8 & $\mathrm{NaCl}$ & 24954.3 & 427.0 & $\mathrm{Cl}$ & 581.5 \\
\hline $\mathrm{SO}_{4}$ & 22.3 & $\mathrm{Na}_{2} \mathrm{SO}_{4}$ & 3160.2 & 22.3 & $\mathrm{SO}_{4}$ & 22.3 \\
\hline $\mathrm{Br}$ & 0.86 & $\mathrm{KBr}$ & 102.6 & 0.86 & $\mathrm{Br}$ & 0.86 \\
\hline $\mathrm{Si}(\mathrm{OH})_{4}$ & 0.43 & $\begin{array}{c}\mathrm{Na}_{2} \mathrm{SiO}_{3} \\
9 \mathrm{H}_{2} \mathrm{O}\end{array}$ & 121.6 & 0.43 & $\mathrm{Si}(\mathrm{OH})_{4}$ & 0.43 \\
\hline B & 0.44 & $\mathrm{Na}_{2} \mathrm{~B}_{4} \mathrm{O}_{7}$ & 21.9 & 0.11 & B & 0.436 \\
\hline $\mathrm{Mn}$ & 0.0011 & $\mathrm{MnSO}_{4} \mathrm{H}_{2} \mathrm{O}$ & 0.19 & 0.001 & $\mathrm{Mn}$ & 0.001 \\
\hline $\mathrm{Ca}$ & 8.22 & $\mathrm{CaCO}_{3}$ & 6.2 & 0.062 & $\mathrm{Ca}$ & 8.22 \\
\hline $\mathrm{Fe}$ & 0.00093 & $\mathrm{FeCl}_{3}$ & 0.15 & 0.0009 & $\mathrm{Fe}$ & 0.0009 \\
\hline $\mathrm{Na}$ & 478 & $\mathrm{NaHCO}_{3}$ & 605 & 7.2 & $\mathrm{Na}$ & $575.7^{\mathrm{c}}, 528.6^{\mathrm{d}}$ \\
\hline $\mathrm{Sr}$ & 0.085 & $\mathrm{SrCl}_{2} 6 \mathrm{H}_{2} \mathrm{O}$ & 22.7 & 0.085 & $\mathrm{Sr}$ & 0.085 \\
\hline $\mathrm{Ba}$ & 0.0004 & $\mathrm{BaCO}_{3}$ & 0.08 & 0.0004 & $\mathrm{Ba}$ & 0.0004 \\
\hline $\mathrm{Li}$ & 0.023 & $\mathrm{Li}_{2} \mathrm{CO}_{3}$ & 0.84 & 0.011 & $\mathrm{Li}$ & 0.023 \\
\hline K & 10.7 & $\mathrm{KCl}$ & 733.5 & 9.8 & K & 10.7 \\
\hline Mg & 50.7 & $\mathrm{MgCl}_{2} 6 \mathrm{H}_{2} \mathrm{O}$ & 10307.8 & 50.7 & $\mathrm{Mg}$ & 50.7 \\
\hline Alkalinity [mEq/l] & 7.35 & $\mathrm{CaCl}_{2}$ & 905.6 & 8.16 & Alkalinity & 7.36[mEq/l] \\
\hline \multirow[t]{3}{*}{$\mathrm{H}_{2} \mathrm{~S} \mathrm{mmol} / \mathrm{l}$} & 345 & $\begin{array}{l}\text { Na-formate } \\
\text { or }\end{array}$ & 6405 & 94.2 & $\mathrm{CHO}_{2}^{-}$ & 94.2 \\
\hline & & $\begin{array}{l}\text { Na-acetate } \\
\text { or }\end{array}$ & 3854 & 47 & $\mathrm{C}_{2} \mathrm{H}_{3} \mathrm{O}_{2}^{-}$ & 47 \\
\hline & & $\begin{array}{c}\text { Na-lactate } \\
\text { Wolf's } \\
\text { vitamin } \\
\text { solution } \\
\end{array}$ & $\begin{array}{r}5324 \\
1 \mathrm{ml} / \mathrm{L}\end{array}$ & 47 & $\mathrm{C}_{3} \mathrm{H}_{5} \mathrm{O}_{3}^{-}$ & 47 \\
\hline
\end{tabular}

(SUESS, 2005)

$\mathrm{b}$ The concentration has been adjusted to achieve a C:N:P ratio of 106:16:1

${ }^{\mathrm{C}}$ In formate containing medium, $[\mathrm{Na}]=575.7 \mathrm{mM} / \mathrm{L}$.

${ }^{\mathrm{d}}$ In $\mathrm{H}_{2}$ or lactate containing medium, $[\mathrm{Na}]=528.6 \mathrm{mM} / \mathrm{L}$. 


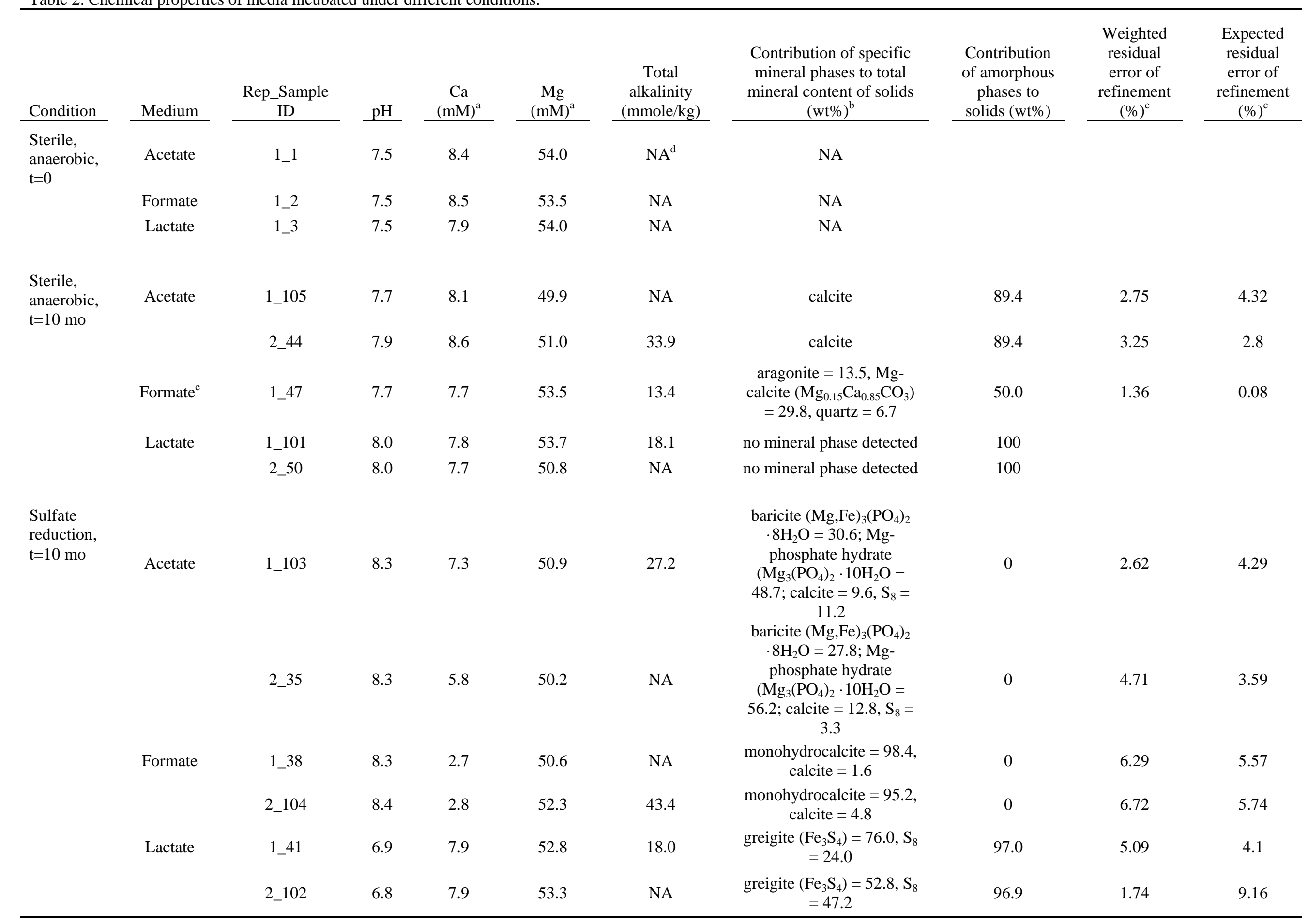

${ }^{\mathrm{a} C}$ Concentration based on ICP-MS results.

${ }^{\mathrm{b}}$ Identity based on XRD analysis.

${ }^{\mathrm{c}}$ Residual error of refinement based on Rietveld full-pattern fitting method

${ }^{\mathrm{d}} \mathrm{NA}$; not analyzed

${ }^{\text {e}}$ One of the replicate bottles containing the formate medium incubated under sterile conditions broke during shipment for analysis. Thus, data was generated from only one of the two replicates for this incubation condition. 
Table 3. EMPA-based chemical composition of minerals formed in formate medium under sulfate reducing condition.

\begin{tabular}{|c|c|c|c|c|c|c|c|c|c|c|c|c|c|c|c|c|}
\hline Replicate_Sample ID & $\begin{array}{l}\mathrm{CaO} \\
\mathrm{wt} \%\end{array}$ & $\begin{array}{l}\mathrm{SiO}_{2} \\
\mathrm{wt} \%\end{array}$ & $\begin{array}{l}\mathrm{Na}_{2} \mathrm{O} \\
\text { wt\% }\end{array}$ & $\begin{array}{l}\mathrm{MnO} \\
\mathrm{wt} \%\end{array}$ & $\begin{array}{l}\mathrm{SrO} \\
\mathrm{wt} \%\end{array}$ & $\begin{array}{l}\mathrm{MgO} \\
\mathrm{wt} \%\end{array}$ & $\begin{array}{l}\mathrm{FeO} \\
\mathrm{wt} \%\end{array}$ & $\begin{array}{l}\mathrm{SO}_{3} \\
\mathrm{wt} \%\end{array}$ & $\begin{array}{l}\mathrm{P}_{2} \mathrm{O}_{5} \\
\mathrm{wt} \%\end{array}$ & $\begin{array}{l}\text { Total } \\
\text { wt\% }\end{array}$ & $\begin{array}{l}\mathrm{CO}_{2} \\
\mathrm{wt} \%\end{array}$ & $\begin{array}{l}\mathrm{H}_{2} \mathrm{O} \\
\mathrm{wt} \%\end{array}$ & $\begin{array}{c}\mathrm{CO}_{2}+\mathrm{H}_{2} \mathrm{O}^{\mathrm{a}} \\
\mathrm{wt} \%\end{array}$ & $\begin{array}{r}\mathrm{Ca} \\
\mathrm{at} \% \\
\end{array}$ & $\begin{array}{c}\text { Relative error } \\
\%^{\mathrm{b}}\end{array}$ & $\begin{array}{l}\text { Mineral } \\
\text { inferred }\end{array}$ \\
\hline 1_38-2 & 55.49 & 0.03 & 0.15 & 0.05 & 0.15 & 0.24 & 1.34 & 1.38 & 2.97 & 61.79 & no data & no data & 38.21 & 98.95 & -1.05 & Calcite \\
\hline 1_38-3 & 56.36 & 0.00 & 0.13 & & 0.13 & 0.15 & 0.16 & 0.17 & 2.19 & 59.29 & no data & no data & 40.71 & 100.50 & 0.50 & Calcite \\
\hline 1_38-4 & 55.21 & - & 0.01 & 0.02 & 0.07 & 0.09 & 0.12 & 0.27 & 2.59 & 58.38 & no data & no data & 41.62 & 98.45 & -1.55 & Calcite \\
\hline 1_38-1 & 43.51 & 0.10 & 0.09 & 0.10 & 0.14 & 0.43 & 1.21 & 0.42 & 3.37 & 49.35 & no data & no data & 50.65 & 77.59 & -3.01 & MHC \\
\hline 2_104-1 & 44.07 & 0.03 & 1.56 & & 0.04 & 0.33 & 0.10 & - & - & 46.15 & no data & no data & 53.85 & 78.60 & -1.76 & MHC \\
\hline 2_104-2 & 45.58 & 0.05 & 0.62 & & 0.07 & 0.06 & 0.01 & - & - & 46.41 & no data & no data & 53.59 & 81.27 & 1.59 & MHC \\
\hline 2_104-3 & 45.96 & 0.03 & 0.56 & 0.03 & 0.05 & 0.05 & 0.18 & 0.36 & 1.49 & 48.71 & no data & no data & 51.29 & 81.96 & 2.45 & MHC \\
\hline 2_104-4 & 46.00 & 0.03 & 0.16 & 0.07 & 0.06 & 0.08 & - & 0.25 & 1.57 & 48.23 & no data & no data & 51.77 & 82.03 & 2.54 & MHC \\
\hline 2_104-5 & 46.48 & - & 0.34 & 0.08 & 0.15 & 0.21 & 0.03 & 0.06 & 1.23 & 48.59 & no data & no data & 51.42 & 82.89 & 3.61 & MHC \\
\hline $\begin{array}{c}\text { Stoichiometric } \\
\text { MHC }\end{array}$ & 47.47 & & & & & & & & & & 37.26 & 15.25 & 52.51 & 80 & & \\
\hline $\begin{array}{l}\text { Stoichiometric } \\
\text { Calcite }\end{array}$ & 56.03 & & & & & & & & & & 43.97 & & 43.97 & 100 & & \\
\hline
\end{tabular}

${ }^{a}$ Because $\mathrm{C}$ and $\mathrm{O}$ were not determined by EMPA, it was assumed that $\mathrm{CO}_{2}$ and $\mathrm{CO}_{2}+\mathrm{H}_{2} \mathrm{O}$ made up the difference between $100 \%$ and the total contents of oxides for calcite and monohydrocalcite, respectively.

${ }^{b}$ Relative error as \%, which was calculated from the atomic percentage of Ca in the samples relative to Ca in corresponding stoichiometric mineral according to the equation $\left.\left[\mathrm{Ca}_{\text {measured }}-\mathrm{Ca}_{\text {stoichiometric }}\right] / \mathrm{Ca}_{\text {stoichiometric }}\right] \mathrm{x} 100$. Elemental composition of stoichiometric minerals was obtained at http://webmineral.com.

Precision was better than $3 \%$ for major elements and 5-10\% for minor elements based on repeated analysis of standards. 